O

doi: $10.5004 / \mathrm{dwt} .2019 .24208$

\title{
Influences of laterite soil towards physico-chemical properties and heavy metals concentration in urban lake quality index
}

\author{
Rashidi Othman*, Wan Syibrah Hanisah Wan Sulaiman, Zainul Mukrim Baharuddin, \\ Lukman Hakim Mahamod, Khairusy Syakirin Has-Yun Hashim \\ International Institute for Halal Research and Training (INHART), Department of Landscape Architecture, Kulliyyah of Architecture \\ and Environmental Design, International Islamic University Malaysia, 53100 Kuala Lumpur, Malaysia, Tel. +60126644772; \\ email: rashidi@iium.edu.my (R.Othman)
}

Received 7 October 2018; Accepted 3 January 2019

\begin{abstract}
A B S T R A C T
The soil is a transmitted agent of water run-off to the water body. Variety of soil type in Malaysia has contributed to the difference of soil properties dissolved in the water and the concern of soil problem in Malaysia involving from laterite, sandy, acid sulfate and organic soil type. Soil properties are one of the subjects of impacting the hydrological composition through transportation of physic chemicals properties that bring all compound result on water quality. Thus, this research aimed to identify the influences of laterite soil towards physico-chemicals properties and heavy metals concentration in an urban lake. The study was conducted at 10 site studies located at the laterite soil area by evaluating physico-chemical properties and heavy metals concentrations by using inductively coupled plasma mass spectrometry. The results established the significant physico-chemical and heavy metal variables that strongly associated with laterite soil urban lake are high value in biological oxygen demand $(62.8 \mathrm{mg} / \mathrm{L})$, chemicals oxygen demand $(15.87 \mathrm{mg} / \mathrm{L}), \mathrm{NH}_{3}-\mathrm{N}(0.58 \mathrm{mg} / \mathrm{L})$, total suspended solids $(59.27 \mathrm{mg} / \mathrm{L})$, slightly acidic of $\mathrm{pH}(6.62)$ and for heavy metals three elements found dominants in water samples such as $\mathrm{Fe}(0.49 \mathrm{mg} / \mathrm{L}), \mathrm{Al}(0.24 \mathrm{mg} / \mathrm{L})$ and $\mathrm{Mn}(0.05 \mathrm{mg} / \mathrm{L})$. The laterite soil samples were dominated by clay (36.1\%) whereas the composition of heavy metals concentration was found high in Fe (676.25 mg/L), $\mathrm{Al}(563.13 \mathrm{mg} / \mathrm{L})$, and $\mathrm{Mn}(1.82 \mathrm{mg} / \mathrm{L})$. The significant outcome of this study can be used as key tools indicator for monitoring urban lakes status and indices.
\end{abstract}

Keywords: Highly weathered soil; Water quality index; Heavy metals contaminant; Urban lake status

\section{Introduction}

The soil is the component that interconnects the earth system and also as a device of hydrological, biological, and geochemical as well as erosional cycles [1]. One of the types of soil problems that dominates in a tropical environment in Malaysia was classified as oxisols as described by soil taxonomy or as known as laterite soil [2]. Land use changes in laterite soil area contributed to the trends of heavy metal concentration in case studies as happened to Tasik Chini in Pahang [3]. Soil and water are significant components for all living organism to form a good ecosystem for living things [4].

Most of the environmental degradation issues had a limitation on the management and field measurement in dealing with the pollution problem [5] including the problems of soil and water. Thus, identifying the influences of laterite soil towards urban lake quality index are important to remain the original physico-chemicals properties and heavy metals content in an urban lake in the safety standard

\footnotetext{
* Corresponding author.
} 
for references of environmental management in future. The physico-chemical properties of the different soil types have different indicators that affect the water bodies surrounding. Water quality degradation also has a strong connection with the toxicity of heavy metals that runoff from the soil surface. To achieve this objective 10 selected urban lake at laterite soil land area was selected to evaluate and further investigate.

\section{Materials and methods}

\subsection{Study area and sampling design}

According to Reconnaissance soil Map Peninsular Malaysia by Agricultural Department 2015, the laterite soil area mostly located in urban land areas such as Kuala Lumpur, Melaka, Seremban, Mentakab, and Port Dickson. It also has been reported by Geological Society of Malaysia that shown in their illustration about the widespread of laterite in the lowland area of Malaysia that normally occur in few situations such as flat alluvial, hill summits, gently undulating country and foot slopes with erosion resistance [6]. The samples were taken from the site of water bodies and soil surrounded by respected water bodies. For an overall assessment, 10 areas were selected with 10 points of the water sample and soil sample for each area. Consequently, a total of 100 water sampling and 100 soils sampling were collected. The identified urban lake for laterite soil land area was listed below:

- L1: Taman Tasik Ampang Hilir, Kuala Lumpur (3॰09'14.9' $\left.\mathrm{N} 101^{\circ} 44^{\prime} 40.9^{\prime \prime} \mathrm{E}\right)$

- L2: Taman Tasik Titiwangsa, Kuala Lumpur $\left(3^{\circ} 10^{\prime} 41.1^{\prime \prime} \mathrm{N}\right.$ $101^{\circ} 42^{\prime} 19.0^{\prime \prime} \mathrm{E}$ )

- L3: Taman Tasik Manjalara, Kuala Lumpur $\left(3^{\circ} 11^{\prime} 39.8^{\prime \prime} \mathrm{N}\right.$ 101³7'39.6"E)

- L4: Taman Tasik Ayer Keroh, Melaka (2॰16'26.7”N $\left.102^{\circ} 18^{\prime} 06.2^{\prime \prime} \mathrm{E}\right)$

- L5: Taman Tasik Bandar Kuantan, Pahang (3॰50'10.0”N $\left.103^{\circ} 17^{\prime} 48.5^{\prime \prime} \mathrm{E}\right)$

- L6: Tasik Chanting Mentakab, Pahang $\left(3^{\circ} 28^{\prime} 01.4^{\prime \prime} \mathrm{N}\right.$ $\left.102^{\circ} 20^{\prime} 59.8^{\prime \prime} \mathrm{E}\right)$

- L7: Taman Tasik Seremban, Negeri Sembilan $\left(2^{\circ} 43^{\prime} 17.1^{\prime \prime} \mathrm{N}\right.$ $\left.101^{\circ} 56^{\prime} 36.2^{\prime \prime} \mathrm{E}\right)$

- L8: Tasik Spring Hill Port Dickson, Negeri Sembilan $\left(2^{\circ} 36^{\prime} 08.5^{\prime \prime} \mathrm{N} 101^{\circ} 51^{\prime} 38.9^{\prime \prime} \mathrm{E}\right)$

- L9: Tasik Taman Botanic Klang, Selangor (2॰59'34.1”N $\left.101^{\circ} 27^{\prime} 11.0^{\prime \prime} \mathrm{E}\right)$

- L10: Tasik Bandar Bukit Raja Klang, Selangor (3.089347, 101.434981)

\subsection{Water sampling preparation}

The water sample was collected about $10 \mathrm{~cm}$ below the water surface [7] at 10 different points for each selected area and due to limited instruments for experiments, the sampling takes a long time to accumulate of total 100 water samples from January to March 2017. The characteristic of water bodies for sampling should be stagnant such as the mechanism of the lake. Surface water samples were collected using HDPE bottles [8]. The whole water sample was preserved in icebox during the time and all the way to the laboratory for analysis. Further analysis on heavy metals in water were analyzed after digestion using microwave digester D startup following US EPA 3015 method for water sample with 1,200 $\mathrm{W}$ maximum power for 10 vessels at $20 \mathrm{~min}$ digestion process and $45 \mathrm{~mL}$ water samples with $5 \mathrm{~mL} \mathrm{65 \%} \mathrm{nitric} \mathrm{acid.This} \mathrm{while,} \mathrm{the} \mathrm{solutions} \mathrm{were} \mathrm{further}$ analyzed by using inductively coupled plasma mass spectrometry (ICP-MS) for heavy metals detection with triplicates each point of samples.

\subsection{Soil sampling and preparation}

Soil samplings were collected at $1 \mathrm{~m}$ from the lakeside out of 10 points around the lake with a $30 \mathrm{~cm}$ depth. Afterward, the samples were air dried at $60^{\circ} \mathrm{C}$ for a week and ground before being sieved $(2.00 \mathrm{~mm})$ then were stored in a sampling bag. All samples out of 10 points were homogenized to be in one sampling container. Each soil sample was analyzed for identifying soil texture, dry $\mathrm{pH}$, organic carbon (OC) and cation exchange capacity (CEC) in the laboratory. Afterward, heavy metal analysis for soil was conducted with $0.5 \mathrm{~g}$ sample which was accurately weighed and placed into the vessels before digesting using microwave digester D start following the method US EPA 3051 for soil with $10 \mathrm{~mL}$ nitric acid and 1,200 $\mathrm{W}$ maximum power. The duration required was $35 \mathrm{~min}$ for overall digestion and cooling process. The solutions were further used for heavy metal analysis by using ICP-MS.

\section{Results}

\subsection{Physico-chemical properties}

The physico-chemical analyses for water are presented in Table 1 established a significant result $(p<0.0001)$ and showed the high value of average in biological oxygen demand (BOD) $(62.8 \mathrm{mg} / \mathrm{L})$ and chemical oxygen demand (COD) $(15.87 \mathrm{mg} / \mathrm{L})$. Both measuring tools are indicators that the water was polluted and in addition on the value $\mathrm{NH}_{3}-\mathrm{N}$ (0.58 mg/L), total suspended solids (TSS) $(59.27 \mathrm{mg} / \mathrm{L})$, slightly acidic $\mathrm{pH}$ (6.62) that contributed to the overall water quality index (WQI) that placed under polluted class IV. Meanwhile, the result of soil samples presented in Table 2 obtained the value of clay (36.1\%) dominant in the soil sample and the average of the soil dry $\mathrm{pH}$ was acidic (5.99). In addition to that, OC result found is low with an average value of $0.99 \mathrm{mg} / \mathrm{L}$ and CEC result found varies and the average was $13.53 \mathrm{~mol} / \mathrm{kg}$.

\subsection{Heavy metals analysis}

The result obtained from the analysis of heavy metals from ICP-MS in Table 3 show that several significant elements in $\mathrm{Al}, \mathrm{Cr}, \mathrm{Mn}, \mathrm{Fe}, \mathrm{Ni}$ and $\mathrm{Zn}$ were found in a water sample in laterite soil land area. Based on the classification of WQI established by Department of Environment, the higher class of heavy metals achieved by Fe $(0.49 \mathrm{mg} / \mathrm{L})$ and $\mathrm{Al}(0.24 \mathrm{mg} / \mathrm{L})$ that categorized under class IV and following by $\mathrm{Zn}(0.02 \mathrm{mg} / \mathrm{L}), \mathrm{Mn}(0.05 \mathrm{mg} / \mathrm{L}), \mathrm{Cr}(0.01 \mathrm{mg} / \mathrm{L})$ that each of the elements classified under class III and Ni $(0.01 \mathrm{mg} / \mathrm{L})$ classified under class II.

For soil sample, as shown in Table 4, the concentration of heavy metals was found according to the significant 

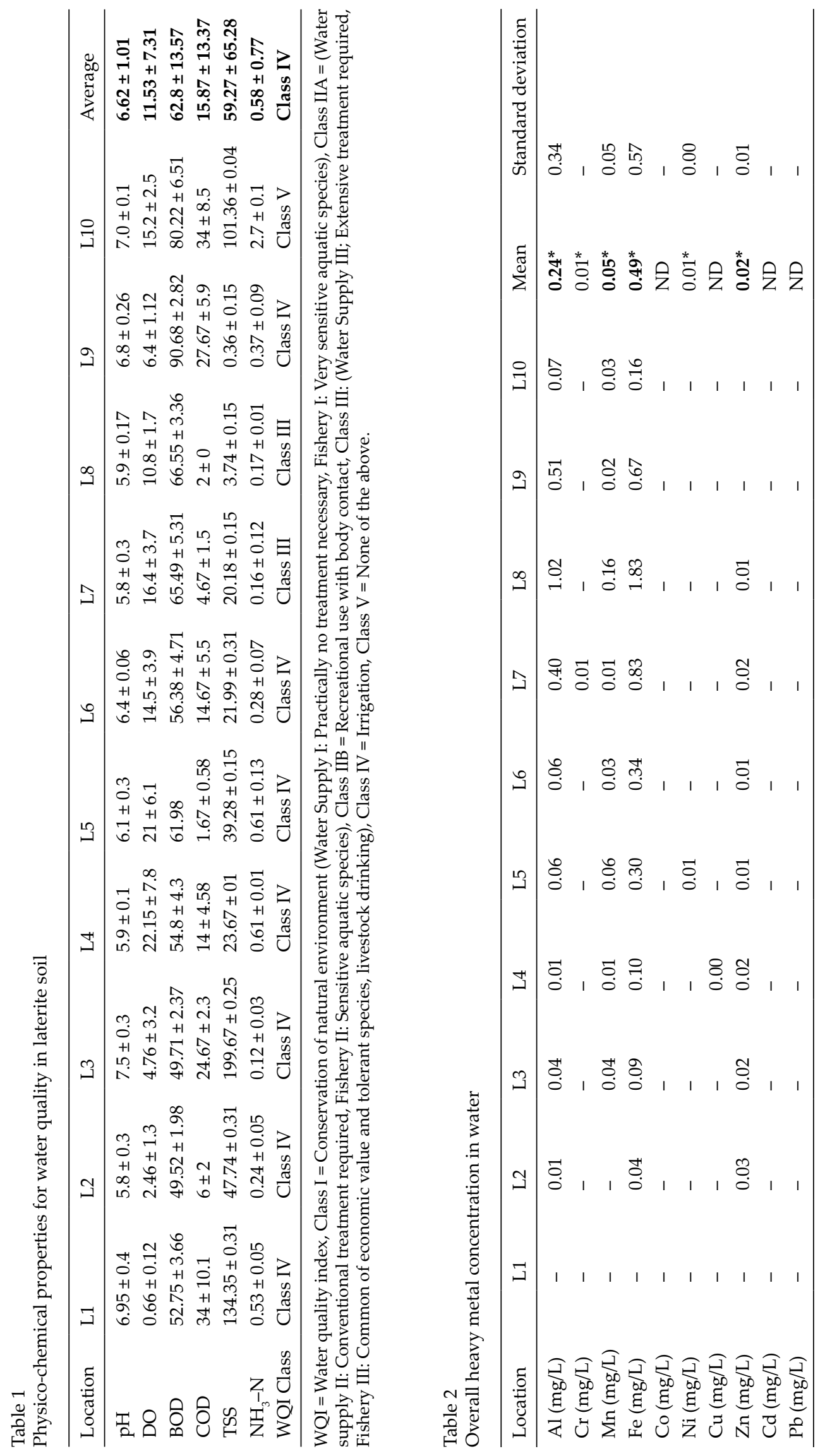

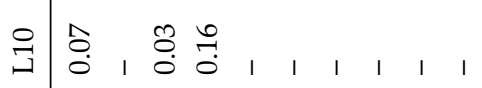

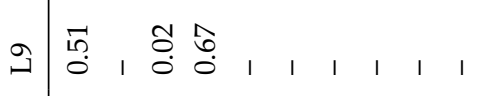

年

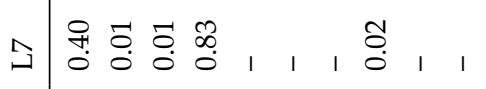

○

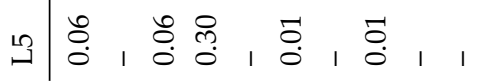

H

3

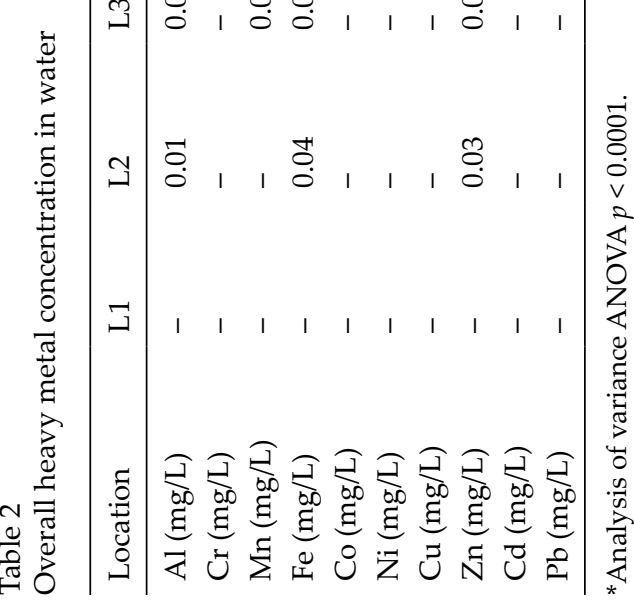




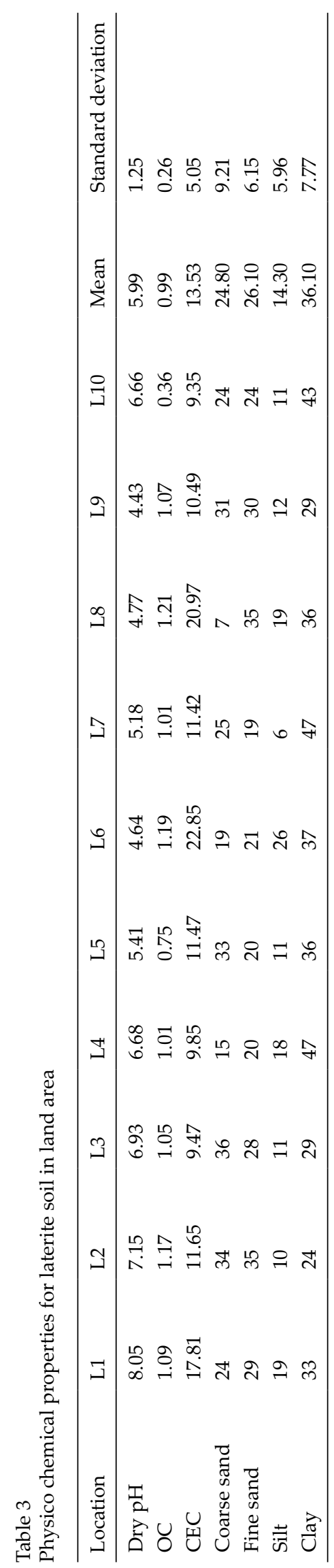

elements of heavy metals that obtained from a water sample. The most significant elements were Fe $(676.25 \mathrm{mg} / \mathrm{L})$ and $\mathrm{Al}(563.13 \mathrm{mg} / \mathrm{L})$. Afterwards, following by Mn $(1.82 \mathrm{mg} / \mathrm{L})$, Zn (1.14 mg/L), Cr (0.93 mg/L) and Ni (0.3 mg/L).

\section{Discussion}

\subsection{Relationship between physico-chemical properties towards WQI}

The analysis showed that the high acidic value in the result of $\mathrm{pH}$ in water indicates the high value in COD and BOD which affected the classification of water quality in laterite land area. The value of COD indicates the level of waste probably contributed from various sources such as industrial activities and the value of BOD signifies the level of pollution in water and indicates the requirement of extensive treatment before being used for any purposes [7]. The value of $\mathrm{pH}$ also represents the reactions that occur in water among the compound and the process particularly related to the compound of carbon dioxide that continual flux in regards to photosynthesis and respiration process that used by aquatic plants and aquatic organism as a factor that controls the acidity and the ion from carbonate and bicarbonate regulate alkalinity in water condition [9]. Another factor that contributed to the low level of $\mathrm{pH}$ was the atmosphere temperature on the site sampling [10]. In addition to that, the value of dissolved oxygen plays an important role as a medium for supporting the respiration of the aquatic organism and determines the level of water quality in water. Next, the value of TSS exceeded the recommended maximum limits proposed by National Water Quality Index which is from 25 to $50 \mathrm{mg} / \mathrm{L}$. $\mathrm{NH}_{3}-\mathrm{N}$ can be a reason of eutrophication that degraded the classes of water quality due to chemical pollutant that influences the high concentration of $\mathrm{NH}_{3}-\mathrm{N}$ [4]. The chemicals pollutant is one of the point sources of industrial activities at the surrounding of the sites that channel the effluents to the water bodies nearby. Besides, $43 \%$ of the rivers in Malaysia are polluted with $\mathrm{NH}_{3}-\mathrm{N}$ [11].

\subsection{Relationship between heavy metals and water quality}

The analysis of variances showed most of the selected elements for heavy metals evaluation was a highly significant difference $(p<0.0001)$ in most of the result except for $\mathrm{Co}, \mathrm{Cu}$, $\mathrm{Cd}$ and $\mathrm{Pb}$. However, based on the WQI classification there were four elements that achieved a certain standard and will further concern which were $\mathrm{Al}, \mathrm{Mn}, \mathrm{Fe}$ and $\mathrm{Zn}$. A first element that contributes to the highest class in WQI was the value of $\mathrm{Al}$ and greatly influenced by the level of $\mathrm{pH}$ and also significantly depending on several physico-chemicals and mineralogical process [12]. All the heavy metals in our atmosphere potentially dissolve in water, so it is possible that the water properties have a small number of metals. However, the excessive value of heavy metals from various point sources such as industrial and mining as occurred in Tasik Chini [3] that influence pollutants, intoxicants and harm to other living things as well as the ecosystem. One fact that was found describing the $\mathrm{Al}$ content more present in acidic soil and occurs in many silicate rocks after the process of oxidation and concentration of $\mathrm{Al}$ in $\mathrm{pH} 5$ and above are very low because there is a small amount of $\mathrm{Al}$ 
in neutral to alkaline soil or sediment that related to water body [9]. A next element found in a water sample in laterite soil land area was $\mathrm{Cr}$. $\mathrm{Cr}$ is a common element that exists in the earth and natural water in very low level. Mn is also one of the common elements that come from point sources such as industrial alloy and give anthropogenic inputs that may have affected the soil texture including parent material and the concentration of Mn normally were higher than $\mathrm{Cu}$ and $\mathrm{Zn}$ on regards of the process oxidation, but $\mathrm{Mn}$ can be removed with Fe oxides during precipitation [13]. Moreover, heavy metals can be distributed and transported in water, soil, sediment or plants and spreading to the environments [14]. In fact, heavy metals originate from the earth and become toxicant to the environment without proper treatment and control [15].

\subsection{Relationship of soil chemicals properties and water quality}

Soil properties have impact on the hydrological composition in a catchment or reservoir including lakes through sediments transportation of pollution that bring all compound result on water quality [7]. The result of soil texture showed the dominant percentage of texture in laterite soil was clay and followed by coarse sand, fine sand and silt. The amount of Cal in soil sample was very low and interrelated to the result of $\mathrm{pH}$ that falls in a group of acidic because there is sufficient Ca carbonate to neutralize the soil $\mathrm{pH}$ [16]. The amount of OC in soil was closely related to the soil texture as a result of impacting the dissolved organic in the water. Since the percentage of clay was higher in soil texture of laterite land area, the small particle of the soil influences the OC moving to the water during the runoff. It was supported in other studies that mentioned, the OC was very low at the sampling area as for the interaction between the land system and the water system surrounding that contribute to the OC cycle [7]. Measuring the OC on the soil sample was significant to avoid the unsafe soil quality and water quality for the benefit of other living things as well as for the public use in the urban area. The earth system was constructed with many key components including soil to control the hydrological, biological, geochemical and erosion cycle, but the exploitation of the resources had degraded the soil structure and soil quality that damaged the original function of the soil [1].

\subsection{Relationship between heavy metals in soil and water quality}

The previous subtopic had discussed the relationship between heavy metal in water and water quality and subsequently, soil properties play a vital role in influencing the condition of water bodies nearby. Thus, sampling of the soil in the same area of water sample had taken were investigated. Based on the result, Fe and Al were found as the highest amount in the soil sample and can be as an indicator for laterite soil land area. The existence of Fe in the soil sample shows the oxido-reduction environment has taken place through translocation and installation of environmental material [17]. Moreover, the result of the soil texture that dominant by the percentage of clay reinforces the reason of the ability of soil properties and character in absorbing the particle from the environment and give a gross indication for 
further process of soil stability that influences the groundwater movement, surface runoff as well as soil erosion [6]. Hooda [13] reported that other elements such as $\mathrm{Cu}, \mathrm{Al}$ and $\mathrm{Fe}$ have an ability to bind with soil and adsorbing $\mathrm{Cu}$ ions from solution through water run-off process as well as adsorbing organic content. It was responding to the result of $\mathrm{OC}$ in the previous sub-topic that present in all sample of soil and the mechanism was depending on the $\mathrm{pH}$ of the soil. The variety of metals found in soil sample influences the value of CEC that influence the toxicity of the soil [18]. Another factor was influenced by leaching of parent materials from the soil horizon that released Fe and Mn [10].

\section{Conclusion}

As a conclusion, the significant physico-chemical and heavy metal influences are strongly associated with laterite soil of urban lake as influenced by the soil texture of clay $>36 \%$ that reflected high value in BOD $(62.8 \mathrm{mg} / \mathrm{L})$, COD $(15.87 \mathrm{mg} / \mathrm{L}), \mathrm{NH}_{3}-\mathrm{N}(0.58 \mathrm{mg} / \mathrm{L}), \mathrm{TSS}(59.27 \mathrm{mg} / \mathrm{L})$ and slightly acidic $\mathrm{pH}$ (6.62). Meanwhile, Fe (0.49 mg/L), Al $(0.24 \mathrm{mg} / \mathrm{L})$ and $\mathrm{Mn}(0.05 \mathrm{mg} / \mathrm{L})$ were found as the indicator water sample of urban lake at laterite soil as a result of the high value of clay percentage in soil texture influence the movement of heavy metals from the soil to the water body. The variables factor from physico-chemicals and heavy metals affected the water quality classification that found dominants in class IV. Thus, overall results can be as a future reference in examining water quality related to the laterite soil area.

\section{Acknowledgments}

The authors are very thankful to International Islamic University Malaysia (IIUM) and Ministry of Higher Education (MOHE) Malaysia for financial support under the grant MOHE 18-001-0001.

\section{References}

[1] A.A. Elisa, S. Ninomiya, J. Shamshuddin, I. Roslan, Alleviating aluminum toxicity in an acid sulfate soil from Peninsular Malaysia by calcium silicate application, Solid Earth, 7 (2016) 367-374.

[2] N.S.M. Radzi, Study on Heavy Metal Content of Highly Weathered Soil as Early Warning System Indicator to Predict Shallow Slope Failure, Master's Thesis, International Islamic University Malaysia, Gombak, Kuala Lumpur, 2014.
[3] Z. Sharip, J. Jusoh, Integrated lake basin management and its importance for Lake Chini and other lakes in Malaysia, Lakes Reservoirs Res. Manage., 15 (2010) 41-51.

[4] A.A. Erakhrumen, Research Advances in Bioremediation of Soils and Groundwater Using Plant-Based Systems: A Case for Enlarging and Updating Information and Knowledge in Environmental Pollution Management in Developing Countries, Biomanagement of Metal-Contaminated Soils, Springer, Netherlands, 2011, pp. 143-166.

[5] A. Shamshad, C.S. Leow, A. Ramlah, W.M.A. Wan Hussin, S.A. Mohd. Sanusi, Applications of AnnAGNPS model for soil loss estimation and nutrient loading for Malaysian conditions, Int. J. Appl. Earth Obs. Geoinf., 10 (2008) 239-252.

[6] R.J. Eyles, Physiographic Implications of Laterite in West Malaysia, Bulletin No. 3: Geological Society of Malaysia, 1970, pp. 1-7.

[7] I.M. Sujaul, M.A. Sobahan, A.A. Edriyana, F.M. Yahaya, R.M. Yunus, Adverse impacts of poor wastewater management practices on water quality in Gebeng Industrial Area, Pahang, Malaysia, Int. J. Environ. Ecol. Geol. Geophys. Eng., 9 (2015) 286-289.

[8] M.A. Hossain, I.M. Sujaul, M.A. Nasly, Water quality index: an indicator of surface water pollution in eastern part of Peninsular Malaysia, Res. J. Recent Sci., 2 (2013) 10-17.

[9] C.E. Boyd, Water Quality, An Introduction, Kluwer Academic Publishers, Boston, 2000.

[10] M.V. Prasanna, S.M. Praveena, S. Chidambaram, R. Nagarajan, A. Elayaraja, Evaluation of water quality pollution indices for heavy metal contamination monitoring: a case study from Curtin Lake, Miri City, East Malaysia, Environ. Earth Sci., 67 (2012) 1987-2001.

[11] A. Al-Mamun, Z. Zainuddin, Sustainable river water quality management in Malaysia, IIUM Eng. J., 14 (2013) 29-42.

[12] H. Ciftci, C. Er, Solid-phase extraction and separation procedure for trace aluminum in water samples and its determination by high-resolution continuum source flame atomic absorption spectrometry (HR-CS FAAS), Environ. Monit. Assess., 185 (2013) $2745-2753$.

[13] P.S. Hooda, Trace Elements in Soil, John Wiley and Sons Ltd. Publications, UK, 2010.

[14] M.A. Ashraf, M.J. Maah, I.B. Yusoff, Study of water quality and heavy metals in soil \& water of ex-mining area Bestari Jaya, Peninsular Malaysia, Assoc. Am. Geogr., 62 (2010) 42-56.

[15] N. Rahmanian, S.H. bt Ali, M. Homayoonfard, M. Rehan, Y. Sadef, A.S. Nizami, Analysis of physiochemical parameters to evaluate the drinking water quality in the State of Perak, Malaysia, J. Chem., 2015 (2015) 1-10.

[16] D. Dent, Acid Sulphate Soil: A Baseline for Research and Development, International Institute for Land Reclaimation and Improvement, The Netherlands, 1986.

[17] J. Shamsuddin, E. Tessen, Clay Mineralogy of Selected Alluvial Soils from Peninsular Malaysia, GEOSEA V Proceedings, Geol. Soc. Malaysia, 1986, pp. 443-451.

[18] R. Othman, S.H. Hasni, Z.M. Baharuddin, Analysis of heavy metals as a key indicator to predict shallow slope failure, J. Environ. Biol., 37 (2016) 1181-1185. 